\title{
The E-Government in Sudan: Challenges, Barriers and Prospects
}

\author{
Quanxi Li \\ Department of Management science and Engineering \\ School of Management, Jilin University \\ Changchun, P.R of China
}

\author{
Elhadi Osman Abdalla \\ Department of Management Information Systems \\ Faculty of Economic and Administrative Sciences, Nile \\ Valley University \\ Atbara, Sudan \\ oamelhadi@yahoo.com
}

\begin{abstract}
The purpose of this study is to illustrate the challenges and barriers encountered in E-Government development and implementation in Sudan. The study described the EGovernment initiatives and pointed out the benefits of $E$ Government which could be realized throughout the adoption of E-Government. The study suggested some priority areas of EGovernment initiatives in Sudan. The study also discussed Sudan E-Government current status. Therefore, it outlined the barriers and challenges impeded Sudan E-Government development. The study stated the country readiness for E-Government adoption weaknesses. Finally, the study recommended that proper orientation should be given to E-Government adoption and development in Sudan.
\end{abstract}

Keywords-component; E-Government; E-Government challenges; Sudan; Sudan E-Government initiatives; EGovernment barrier.s

\section{INTRODUCTION}

Technology has always been a driver and an enabler for changes. In recent ICT availability has increased and applied in every domain. The early uses of ICT were applied to automating the existing process through electronic media for example internet; later on ICT has been used to transform the way in which the all operations are done. Nowadays the international trend is towards online service delivery and greater citizen interaction, this interaction and service delivery can be achieved through the uses of new technologies. The EGovernment paradigm means rendering of government services and information to public using the electronic media. The new shape of government has brought a revolution in the quality of services delivered to the citizens. It has ushered in transparency in the governing process; saving the time due to provision of service through single window; simplification of procedures; better office and record management; reduction in corruption and improved attitude, behaviour and job handling capacity of the dealing personnel [1] . At the beginning of the internet revolution organizations and companies uses the internet to adopt e-business and e-commerce, in public sector the comparable term is the e-government [2]. E-Government is not merely the computerization of a government system, but a belief in the ability of technology to achieve high levels of improvement in various areas of government, thus transforming the nature of politics and the relation between government and citizens [3].In developed and some developing countries e-government employment improved the citizens life due to providing at least all necessary services and required information in most aspects in electronic context which results in promoting and enhancing this countries citizens life.

E-Government enables citizens to handle more transaction such as renewing the licenses and pay their tax online. The quantity of these e-transactions increases and the administration is pushed to build online interfaces directly connected to the internally functioning government systems with minimal interaction with government staff [4]. Sudan elaborated a strategy for e-government in 1997 with specific attention to developing a telecommunications infrastructure [5].The government of Sudan create a council for information co-ordination to co-ordinate the E-Government strategy. Most recently, Sudan has started elaborating an action plan to guide the implementation of the actions in the strategy. Despite the support of the private sector, the biggest challenge remains lack of funding for E-Government development [5]. Sudan regardless the numerous uses of technologies particularly the mobile phone services which three companies are competed but E-Government project adoption and implementation is still far behind. But due to expansion of internet uses in recent there are some public sectors in Sudan such as Ministry of Interior, Ministry of High Education and Scientific Research and Sudan Electricity Company provides online services but their websites for services provision is still one way websites.

\section{A. E-government definition}

Many studies and researchers defines E-Government, some definitions restrict E-Government to internet-enabled applications only, while E-Government mainly concentrate on all ICT applications not only internet to improve the activities of public sector organizations. At following we illustrate some studies and researcher definitions and then at the bottom we give a summary and conclude to E-Government definition.

E-governance is the public sector's use of the most innovative information and communication technologies, like the Internet, to deliver to all citizens improved services, reliable information and greater knowledge in order to facilitate access to the governing process and encourage deeper citizen participation [6]. 
E-governance is the digital use of information technology utilized for completing administrative transactions, providing services and communicating with citizens with more democracy and automate the interaction between government departments on the one hand and government departments, business sector and citizens on the other hand [7].

E-Government is simplifying services and procedures and exchanging the information electronically among the different community sector, as well as promoting government work efficiency [8].

We concluded from these definitions that E-government is the use of technologies (ICT) and its applications to facilitate the operation of the government throughout system automation of different government departments and organizations. The utilization of the technologies will make the access of government information and services easy to the stakeholders.

In other words we can Say E-Government is the use of technologies to facilitate the operations of the government which enable the access to the government information and service.

\section{B. Benefits of E-government}

Although the implementation E-Government can result in cost reduction to government and citizens, alike increase transparency and reduce corruption in public services delivery. E-Government can transform old challenges and create unprecedented possibilities for sustainable economic development, just as it has done for business in the industrial worlds [9].

So, E-Government implementation brings many benefits to public and private sector to improve their performance. Ref. [6] outlined the main benefits of E-Government as follows:

- Cost reduction and efficiency gains

- Quality and flexibility of service delivery to businesses and customers.

- Increase transparency and accountability also eliminated corruptions.

- Increase the capacity of government

- Network and community creation

- Improve the quality of decision making through the provision of requires and accurate information.

- Promote the use of ICT in other sectors of the society.

- Citizens satisfactory due to provide them the information they required in easy and fast way.

\section{THE PROSPECTS OF E-GOVERNMENT IN SUDAN}

The E-Government project in Sudan is the responsibility of the National Information Centre (NIC). This centre was formed in 2004, and it is in charge of all ICT related projects within government [10]. Initially the centre worked under the command of the Council of Ministers. After the creation of the
Telecommunications and Information Technology Ministry, the NIC became one of its administrations.

The E-Government project implementation will carry out the daily process automation and reengineering the existing process for optimizations to save time and cost. E-Government implementation will offer opportunities for citizens, business and others stakeholders to participate in decision making by allowing them to provide and share their own ideas and suggestion in online communities.

The government of Sudan has carried out few projects for E-Government implementation comparing with others nations adopted E-Government projects. For example Sudan government has carried out National Identification System which started in 2010, E-Passport in the year 2009 and Elicense and others. Although E-Government encompasses a wide range of activities and areas, we can concentrates on some public sector institutions in Sudan have priorities to adopt E-Government in their work to improve the work and performance as follows:

\section{A. Education}

Education field E-Government can enable through the following:

School and institutes online management or electronic management, which enable and speedup the information flow in and between the school and the local education administrations, states ministry of education and federal ministry of education. Also, the application of E-G in the education sector could promote the school and families digital interaction, save a staff records for promotions and training chances even so, illustrate the needs of staff appointment and so on.

\section{B. Health field}

The implementation of E- Government will enhance the possibility of the hospital clinical information automation which lead to electronic health records and online emergency desk, thus result in digitalization of prescription and medical certificate cycle. All these can promote the citizen life due to expedite and easiness of delivering the government services throughout using the new technologies.

\section{E-Justice}

The implementation of E- Government could result in improving the productivity and efficiency in the justice system; this can be achieved through keeping electronic records of justice to fastening the sort, storage and retrieval of the needed records. In recent apart from justice cases the court administration in Sudan has established computerize land management systems to overcome the land registration problems.

\section{Electronic office environment}

E-Government will lead to assigning tasks electronically, accessing documents online, meeting schedule and mail checking electronically all these lead to reduce the use of papers which will help in cost reduction in office tasks 
after period of time, also the processes will be handle in accurate and short time.

\section{SUDAN E-GOVERNMENT INITIATIVES}

For Sudan to flourish and prosper need to become innovative users of Information and Telecommunication Technology (ICT), and have a high performing government that providing efficient electronic services to all citizens, thus there are some public sectors institutes initiated to adopt and implement web services to provide, deliver and disseminate services and information to the public such as the following institutions:

\section{A. MOHE E-Government initiative}

MOHE (Ministry of High Education) established National Universities Network (NUN) project with aim of facilitating access to information and delivering services electronically. Therefore, there are two main initiatives under the NUN project:

\section{- The Sudanese universities information network}

- The Sudanese universities virtual library

The goal of these initiatives is to provide connectivity among educational institutions, increase sharing of knowledge, guide the universities and the institutes to build their information infrastructure and enable digital libraries.

This project has serves a large number of students and staff members.

\section{B. EBS E-Government initiative}

CBOS (Central Bank of Sudan) in 1999 established EBS (Electronic Bank System) the company introducing technological banking solutions with aim of linking the banks electronically through the country and provide electronic payment services in and out of the country. EBS started its activity in mid 2000 and began project implementation in early 2001 [11].This initiative results in changing the old bank system to modern fast and efficient bank systems, due to EBS adopted several services such as National Electronic Cheque Clearance, Card Personalization Services and Banking Information Network Services etc.

\section{NEC E-Government initiative}

The NEC (National Electricity Corporation) developed prepaid electricity services to eliminate the bills loses due to the old system implementation. With the adoption of the new system the NEC provide every customer with identification card and number to make the services easy and fast, so even the customer can order the electricity through his mobile device. NEC carried out its initiative and the process of change and use of ICT was introduced in the all departments of NEC.

\section{MI E-Government initiative}

Ministry of Interior established a company in 2006 in order to introduce E-Government initiatives in its work. The MI is concerned with computerizing the police work to gain the technologies advances. The company has two initiatives which are E-passport and the Civil Registration Record (National ID). As the result of the use of technology in MI daily official work the services delivery to citizens has improved.

\section{SUDAN READINESS FOR ADOPTING E-GOVERNMENT WEAKNESSES}

The government of Sudan adopted e-government as a solution to facilitate communication and connectivity between different parts of the government institutions and departments. But indeed there are some weaknesses in Sudan readiness which impeded the implementation of E-Government such as follows:

- Cultural diverse and fragmentations among the citizens (language, religious, etc...) which make it difficult to achieved a unique level of citizen's satisfaction.

- Political instability due to the long war in the south before the country separation in 2011 also the recent ongoing conflict in Darfur, Blue Nile and South Kordfan which have distracted the attention of the politicians and leaders to another mission than the EGovernment adoption and development.

- The embargo and sanction on Sudan since 1996 particularly the technological sanction led to the country isolation and has great impact on influencing the country ICT and its projects development which EGovernment is one of them.

- $\quad$ Lack of ICT skills and well-trained staff which lead to the creation of the change resistance. Moreover it can be noted that most of the professional in the IT field has immigrate to Arab States due to low salary and income.

\section{SUDAN E-GOVERNMENT CHALLENGES}

According to UN report on E-Government development index and world E-Government development ranking in the years 2010 and 2012 Sudan index in the year of 2010 was 0.2610 and the world ranking 154. In the year of 2012 the index was 0.2542 and world ranking 165.According to these figures it seem clear that Sudan has not move ahead while most countries in the same region has increased their EGovernment value such as Tunisia, Algeria and Morocco. The adaptive challenges of E-Government go far beyond technology; they call for organizational structures and skills, new form of leadership, transformation of public-private partnerships [12]. E-Government project implementation in developing countries facing many challenges and barriers, we briefly discuss each of this challenge.

\section{A. Information privacy and security}

Security and privacy of information is a serious technical challenge confronting E-Government implementation all around the world [13]. The internet usage and internet penetration has increasing significantly in Sudan. So, the security has become more critical factor in ensuring 
information and data privacy and protection. The individuals feel that using website to transfer their personal information, and sharing information with public agencies is not safe. They will be afraid that E-services websites are not secure enough to protect their private information from being misused by the hackers. E- Government success requires information flow in secure manner. NTC has to determine the security standards and measurements to build up a mature E- Government. The main obstacle in Sudan as noted by Ref. [14] is that "Citizens and civil service employees lack the required knowledge and awareness of information privacy and security... this can cause a lot of harm, therefore public organizations and civil societies should work together to tackle the problem". The Sudan delegation stated that unilateral sanctions have restricted its access to export markets and affected its ability to import technology and industrial infrastructure necessary for the growth of its productivity [15]. This sanction has limited Sudan relationship with large international ICT companies. This badly affected foreign ICT investment in Sudan, due to prevention of ICT companies from USA and Western Europe to build a partnerships and participating in Sudan projects. The impact of this embargo reflected on the information security in Sudan which leads to the use of open access software's in the websites design and development.

\section{B. Human resource training}

This includes lack of computer literacy among the citizens, and government sector employees who assumed to adopt E-Government to overcome this problem a lot of training in ICT sector has to be handled. In Sudan a lot of people whom have skills in IT sector have has immigrated to Arab States the reason is the low salary and income.

Therefore, lack of citizen awareness and participation in EGovernment implementation particularly to trust and deal with ICT technology to send and receive information or in other words to use it for fulfilling their governmental services. In addition Ref. [16] noted that the main reason behind EGovernment project failure in developing countries is gap experienced between the design and reality implementation of information system.

\section{Change management}

Change management is seen as the most difficult task facing public organizations when replacing existing, traditional procedures. This is because each and every staff member has to help and support the change in organization management. The planning and designing of change management for complex organizations is hard enough let alone applying and implementing such change. Ref. [6] noted that change management can be divided into two sub-concepts: Change Management Approach and Management of Resistance to the change.

Change management approach refers to the change management procedures established within organizations. The change Resistance is refers to employees' fear of ICT replace and job losses. So, to implement and adopt E-Government the traditional management has to change, the governments employees must accept the change in the management which mainly rely on information technology to deliver, receive and store the data and information.

\section{Accessibility}

The growth of E- Government will transform the way government interact with external bodies and individuals, it also transform much of the work undertaken within government. E- Government focuses on two-way or multi-way interaction between government and individual citizen or other organization. It aims to undertaken of all function not just to provide information [2]. Government agencies and departments needs to deliver and receive information in order to undertake a transaction or function. At the same time citizens and business agencies needs to receive and deliver information within the government department.

From these aspects accessibility means that the rights of both sides to access to the information required. In developing countries such as Sudan because of many citizens have no accessibility infrastructures so the country requires establishing computer kiosks for the citizens to meet the accessibility requirements.

\section{SUDAN E- GOVERNMENT BARRIERS}

UN report noted that LCDs countries which Sudan is among them E-government remains hampered by a lack of infrastructure, both physical and human. Despite the advances in mobile communication lack of functional skill limit user uptake [17].

- Lack of integration of administrative simplification with e-government development plans.

- Lack of infrastructure and human resource capacity

- Gap between e-services supply and demand.

- Lack of technical skills

- High cost of technology

- Ineffective government regulations

Furthermore, a plan for implementing E-Government, designed by ICT in Sudan has highlighted number of risks that may impede the development of E- Government adoption [18] these risks include:

- Weak support from senior politicians

- Economic boycott and technological sanction on Sudan.

- Resistance to change in civil service

- Inadequate funding

- $\quad$ Lack of trust to use ICT technologies

\section{CONCLUSION AND RECOMMENDATIONS}

\section{A. Conclusion}

Because of information technology and communication has become a key factor in every field Sudan must pursue 
more active role in the formulation of national policies and strategies to promote the information technologies, to reap a huge benefits in terms of economic and social development. EGovernment adoptions reshape the public sector activities and processes, building relation between citizens and the government, enhancing transparency and increasing government capacity. Based on the analysis of Sudan EGovernment the study found that Sudan still need more work to adopt and implement E-Government project. The study revealed that there are many challenges and barriers impede Sudan E-Government development and implementations. Egovernment is channel which through it the governors interact with citizens, so as long as far Sudan need to adopt EGovernment to promote and make service delivery easier to the citizens.

\section{B. Recommendations}

Government has to adopt number of initiatives to eradicate ICT illiteracy and emphasized the need for establishing database centers.

Government has to introduce the benefits of E-Government to the individuals in rural and urban areas and even among civil services sectors which will result in the demand of EGovernment facilities.

Government should launch new initiatives throughout increase number of computer centers and kiosks and provide more IT training programs which could result in building information-based society.

Establishing unified standards for storing, archiving, sharing and managing data and information. Because without standard classification of information and documentation it will be very hard to reap the benefits of E-Government. As in Reference [14] stated "we need to build strong and powerful database systems, refine public data and carefully manage information ... otherwise e-government will be meaningless and the Public sector will have poor levels of effectiveness".

\section{REFERENCES}

[1] Monga, A., "E-government in India: Opportunities and challenges", Journal of Administration \& Governance, Vol. 3. No. 2,2008 ,pp 52-61.

[2] Australian Government. information management office," future challenges for E-Government", institute of public administration ACT Division volume 1.

[3] Danish Dada, "The Failure of E-Government in Developing Countries: A literature Review", The Electronic Journal on Information Systems in Developing Countries 26, 7, 2006, pp 1-10.

[4] Oreste Signore , Franco Chesi, Maurizio Pallotti , "E-Government: Challenges and Opportunities", CMG Italy- XLX Annual Conference, 2005.

[5] High level Seminar on Measuring and Evaluating E-Government and 3rd Meeting on Working group2 on E-Government and Administrative Simplification, Dubai, March 2007.

[6] Ndou, V., "E-government for developing countries: opportunities and challenges". The Electronic Journal on Information Systems in Developing Countries vol.18 No.1,2004, pp 1-24.

[7] Suha Hameed, Adnan Al-Shawabkah, Role of E-Government in Improving Organizational Performance in the Civil Status and Passports Department of Jordan, Developing Country Studies, Vol.3 No.5, 2013 pp 50-64.
[8] NIC ,"Sudan e-government master plan", Khartoum: National Information Centre, 2007a.

[9] Nugi Nkwe, E-Government: Challenges and Opportunities in Botswana, International Journal of Humanities and Social Science Vol. 2 No. 17;2012, pp 39-48.

[10] NIC , "Sudan e-government master plan", Khartoum: National Information Centre, 2007b.

[11] EBS website, http://www.ebs-sd.com/en/ebs-in-figures.php retrieved on september 2013.

[12] Allen, A.B., Juillet, L., Paquet, G. and Roy, J., "E-Governance and Government Online in Canada: Partnerships, People and Prospects", Government Information Quarterly, Vol.18,2001,pp93-104.

[13] Layton, T., "Information Security: Design, Implementation, Measurement, and Compliance". Boca Raton, FL: Auerbach publications, 2007.

[14] SARA ABDALLA, “An e-government adoption framework for developing countries: A case study from Sudan”, Ph.D. Dissertation, CRANFIELD UNIVERSITY, 2012.

[15] united nation, "Unilateral economic measures as a means of political and economic coercion against developing countries", Macroeconomic policy questions: international trade and development, 2011.

[16] Heeks, R., "Most egovernment-for-development projects fail: How can risks be reduced?", Institute for Development Policy and Management. Universitv of Manchester.2003.

[17] .united nation, e-government survey 2012, "e-government for the people", econonmics \&social affairs, 2012.

[18] NIC ," oriented plan for e-government “, Khartoum: unpublished plan, 2010. 